\title{
Caudal Anesthesia: Experience in the Post-Operative Analgesia in Pediatric Ambulatory Surgery at the University Hospital of Treichville
}

\author{
P. D. Ango ${ }^{*}$, K. L. Kohou ${ }^{2}$, N. Koné ${ }^{1}$, A. Kouamé1, A. M. Y. Tchimou ${ }^{1}$, A. Akremy¹, S. R. Bamkolé ${ }^{3}$, \\ N. Boua ${ }^{1}$, Y. Brouh ${ }^{4}$
}

${ }^{1}$ Departmentof Resuscitation and Anesthesia, University Hospital Center of Treichville (CHUT), Abidjan, Cote d'Ivoire

${ }^{2}$ Department of Resuscitation and Anesthesia, Heart Institute Department of Abidjan (ICA), Abidjan, Cote d'Ivoire

${ }^{3}$ Pediatric Surgery Department, Abidjan, Cote d'Ivoire

${ }^{4}$ Department of Resuscitation and Anesthesia, University Hospital Center of Cocody (CHUC), Abidjan, Cote d'Ivoire

Email: *privatango@yahoo.fr

How to cite this paper: Ango, P.D., Kohou, K.L., Koné, N., Kouamé, A., Tchimou, A.M.Y., Akremy, A., Bamkolé, S.R., Boua, N. and Brouh, Y. (2017) Caudal Anesthesia: Experience in the Post-Operative Analgesia in Pediatric Ambulatory Surgery at the University Hospital of Treichville. Open Journal of Anesthesiology, 7, 400-406.

https://doi.org/10.4236/ojanes.2017.712041

Received: November 3, 2017

Accepted: December 25, 2017

Published: December 28, 2017

Copyright (c) 2017 by authors and Scientific Research Publishing Inc. This work is licensed under the Creative Commons Attribution International License (CC BY 4.0).

http://creativecommons.org/licenses/by/4.0/ (c) (i) Open Access

\begin{abstract}
Introduction: The caudal anesthesia is used by many authors for postoperative analgesia. The purpose of this study was to report our experience in the practice of caudal block as post operative analgesia method in ambulatory surgery in a context of limited technical equipment. Patients and Method: Over a period of 5 months, a prospective study was conducted on 39 children aged 3 to 5 years weighing on average $15.12 \mathrm{~kg}$. Children classified ASA I and II were selected. After premedication with midazolam $(0.3 \mathrm{mg} / \mathrm{kg})$ by intra rectal route, the inhalation induction was made with sevoflurane $8 \%$, conveyed by fresh gas $\left(50 \% \mathrm{O}_{2}\right.$ and $50 \%$ air). The caudal block was obtained with the levobupivacaine $0.25 \%$ at a dose of $1 \mathrm{ml} / \mathrm{kg}$. The hemodynamic parameters (systolic and diastolic blood pressure, heart rates) and respiratory parameters (respiratory frequency) pre-, per- and post-operative were measured. Postoperative pain was assessed with the Objective Pain Scale (OPS). The date of first use of analgesia was noted. The adverse effects of caudal block (meningitis, respiratory disorders, acute urinary retention, cardiac disorders) have been assessed. Results: The average duration of the procedure was 55.2 minutes. The use of analgesia was made 4 hours after skin closure, when the OPS Broadmann score was greater than 3. An agitation was observed in 6 children. Haemodynamic parameters have not significantly varied from the pre- to the post-operative. No infectious complications or intolerance to local anesthetics were observed. Allthe children were able to drink 4 hours after the end of the
\end{abstract}


intervention and issued their first urine later than 3 hours after surgery. Conclusion: This type of anesthesia has been found very suitable for ambulatory surgery of the child, and is always helpful. It assured a post operative analgesia of good quality, and a reduction in consumption of morphine intraoperatively.

\section{Keywords}

Caudal Anesthesia, Postoperative Analgesia, Ambulatory Surgery, Children

\section{Introduction}

Caudal anesthesia finds its place in the per- and post-operative analgesia of almost all interventions involving the lower abdomen and lower limbs; especially in infants and young children [1] [2] [3] [4] [5]. It is safe and effective to receive a sufficient period of analgesia, regardless of the type of surgery [6] [7] [8] [9] [10]. This technique was the most used but nowadays it is increasingly neglected in favor of Ultrasound guided peripheral blocks [11]. However, despite our limited technical equipment, the caudal anesthesia is always practiced [1] [2]. The aim of our study was to report our experience of the practice of the caudal block as a method of postoperative analgesia in ambulatory surgery in Abidjan.

\section{Materials and Method}

This is a prospective study conducted over a period of five months (From 1st January to 31st May 2017). All the children were seen in pre-anesthesia consultation, which made it possible to retain children of ASA I and II.

After obtaining informed consent from both parents (father and mother), 39 children aged 3 to 5 years were selected for a lower gastrointestinal and urological surgery and removal of osteosynthesis material (Table 1). We excluded all surgical emergencies, children with spina bifida or bleeding disorders.

Table 1. Surgical indications.

\begin{tabular}{ccc}
\hline Interventions & Male (sex) & Female n (\%) \\
\hline IH + Circumcision & $15(100)$ & $0(0)$ \\
Hernia of the ovary & $0(0)$ & $6(100)$ \\
Inguinal hernia & $3(100)$ & $0(0)$ \\
Removal of osteosynthesis \\
equipment \\
Testicular Ectopia \\
Umbilical hernia & $1(33)$ & $2(67)$ \\
Total & $5(100)$ & $0(0)$ \\
\hline
\end{tabular}

$\mathrm{n}=$ number, $\mathrm{IH}=$ inguinal hernia. 
The preoperative fast was 2 hours at least, the children drank apple juice (75 $\mathrm{ml}$ to $200 \mathrm{ml}$ depending on the age) 2 hours before induction. The children were admitted at 7 in the morning of surgery. We administered $0.3 \mathrm{ml} / \mathrm{kg}$ of midazolam by intra rectal route half an hour before induction.

The inhalation induction was performed with $8 \%$ of sevoflurane, conveyed by a mixture of fresh gases (50\% oxygen and $50 \%$ Air) then the application of a normal saline infusion according to 4-2-1 protocol adapted to the weight of each child. Three micrograms per $\mathrm{kg}$ of fentanyl were injected through directly intravenous use.

Propofol was injected at a dose of 2 milligram $(\mathrm{mg})$ per $\mathrm{kg}$ to complete the inhalation induction. All the children were intubated and put on a respirator, after the eyes were well centered and fixed.

After induction, the concentration of sevoflurane was reduced to $2 \%$. The children were placed in left lateral decubitus; thighs bent over the pelvis. We spotted the sacral hiatus and a skin aseptic techniquewas performed. only $1 \mathrm{ml}$ of test dose of lidocaine adrenaline in the sacral canal has been injected. One minute later, a single dose of $1 \mathrm{ml} / \mathrm{kg}$ according to the scheme of Armitage, not exceeding $20 \mathrm{ml}$ of levobupivacaine $0.25 \%$ was injected at an angle of $40^{\circ}$ to $60^{\circ}$. Aspiration tests during injection are performed frequently. The needle is removed once the injection is completed and the child is placed in a supine position after a local dressing. A Tuohy needle (short bevel $24-24 \mathrm{~g}$ ) for caudal anesthesia was used for injection into the sacral canal.

The following parameters were measured using a monitor: Non-invasive systolic blood pressure (SBP), diastolic blood pressure (DBP), mean blood pressure (MAP), heart rate (HR) and respiratory rate (RR) during pre, per and post operative period.

In the recovery room, the post operative pain was evaluated with the Objective Pain Scale (OPS) of Broadmann, every 30 min, until the exit of the patient. A score greater than 3allowed the use of injectable paracetamol at the dose of 15 $\mathrm{mg} / \mathrm{kg}$ with or without ibuprofen $(7.5 \mathrm{mg} / \mathrm{kg})$. The duration of the motor block was also evaluated. Children were reviewed on the third day, then a week later to search neuro meningeal complications.

The data were collected using an individual survey form. Data entry and data analysis were done using Epi Info 7.1. The analysis was made with the Statiscal Package for Social Sciences 8. The parameters are expressed in mean \pm standard deviation (extreme value). A value of $p<0.05$ was considered significant.

\section{Results}

Of the 39 children, there were 13 girls and 26 boys.

The average age was $3.9 \pm 0.7$ ( 3 to 5.4 ) years. The average weight was $15.12 \pm$ $3.4 \mathrm{~kg}$. The average duration of surgery was $55.2 \pm 14.5$ minutes. The surgicalindications are shown in Table 1. Hemodynamic parameters pre, per, and postoperative are shown in Table 2. Until the release of the hospital, postoperative pain score was evaluated and shown in Table 3. A rescue analgesia 
Table 2. Hemodynamic parameters.

\begin{tabular}{ccccc}
\hline & Pre anesthesia & Per anesthesia & Post anesthesia & probability \\
\hline SBP (mmHg) & $91.6 \pm 6.3$ & $89.1 \pm 6.1$ & $92.9 \pm 5.5$ & NS \\
& $(81-105)$ & $(79-99)$ & $(79-102)$ & \\
DBP (mmHg) & $39.3 \pm 3.8$ & $42.4 \pm 2.9$ & $38.9 \pm 2.2$ & NS \\
& $(31-48)$ & $(37-47)$ & $(32-43)$ & \\
MBP en mmHg & $39.1 \pm 2.4$ & $59.9 \pm 2.04$ & $39.5 \pm 3.16$ & NS \\
& $(32-45)$ & $(55-65)$ & $(33-45)$ & \\
HR (beats/min) & $101 \pm 10.6$ & $100 \pm 2.4$ & $92.01 \pm 12.3$ & NS \\
& $(92-119)$ & $(87-104)$ & $(86-123)$ & \\
RR (cycle/min) & $20.16 \pm 3.9$ & $21.05 \pm 2.14$ & $22 \pm 2.3$ & NS \\
& $(18-27)$ & $(19-26)$ & $(17-24)$ & \\
\hline
\end{tabular}

Results $=$ mean \pm standard deviation (minimum-maximum). NS $=$ Not significant difference $(\mathrm{p}<0.05)$.

Table 3. Average of post anesthesia OPS (Objective Pain Scale).

\begin{tabular}{cccccc}
\hline Time in hour & T1 & T2 & T3 & T4 & T5 \\
\hline OPS & $1.36 \pm 0.48$ & $2.48 \pm 0.5$ & $3 \pm 00$ & $3.46 \pm 0.5$ & $0.61 \pm 0.54$ \\
\hline
\end{tabular}

Results $=$ average \pm standard deviation (minimum-maximum). $\mathrm{T} 1=2$ hours 30 minutes $; \mathrm{T} 2=3$ hours ; $\mathrm{T} 3$ $=3$ hours 30 minutes; $\mathrm{T} 4=4$ hours; $\mathrm{T} 5=4$ hours 30 minutes.

was performed 4 hours after skin closure. The average duration of motor blockwas $2.82 \pm 0.43$ hours. No intravascular injection was observed. Fentanyl was not reinjected intraoperatively. Six (6) children presented a emergence agitation, two after the 15th minute and another 4 after the 30th minute of the skin closure. The taking of liquid feeding occurred 4 hours after surgery. No infectious complications were noted. The hemodynamic and respiratory parameters have not been modified. All children are issued their first urine before the 4th hour before leaving the hospital.

\section{Discussion}

\section{Limitation of the Study}

The cost of the equipment (Tuohy needle and levobupivacaine) was at the charge of patients (who did not have health insurance), which was a limit to the choice of this practice and thus explained the small size of our study population.

In this study, the caudal anesthesia has allowed an effective post-operative analgesia in the child having receivedan ambulatory surgery. It is interesting and easy to perform [5] [8] [11] [12]. The addition of an adrenalineprolongs the duration of the analgesia and permits to quickly detect an intravascular injection of local anesthetic. This accident of the intravascular injection was not found in this study.

Once little practiced, peripheral blocks represent nowadays the regional techniques most used in many surgical indications in children [11]. 
They are performed by single injection or continuous infusion using a fixed catheter [11] [12]. This new trend is explained by the fact that the caudal block (formerly more used) has a high morbidity: accidental intraspinal and intravascular injections of local anesthetic. The use of ultrasound in the peripheral blocks offers a safety and a clear cut efficiency: permanent visual control of the needle and the diffusion of the local anesthetic, control of the volume of the injected dose [13] [14].

The principle of the caudal anesthesia is based on the fact that the sacral hiatus opens directly on the sacral canal representing the caudal end of the spinal canal. The latter contains the latest spinal roots forming the cauda equina and the filum terminal.

Levobupivacaine is widely used clinically in caudal and spinal anesthesia $[2,4]$ to manage acute and chronic pain. It acts on pain by inhibiting the activity of NMDA receptors (N Methyl D Aspartate) in the dorsal horn of the spinal cord [16]. It blocks the sodium channels and decreases their secretions. It would accelerate the disintegration of synaptic currents NMDA receptor at the normal synaptic transmission [15]. These effects have permited us to obtain a period of long action, allowing an adequate postoperative analgesia [16] [17]. The caudal anesthesia was used as a method of postoperative analgesia by many authors [1] [4] [15] [17] without major hemodynamic and respiratory changes [17]. this technique can also be interesting, in emergency,in the treatment of strangled inguinal hernia or testicular torsion [5] [10].

The Midazolam used in premedication has reduced plasma levels of local anesthetic in the children [9]. This decrease in plasma levels could explain the absence of intolerance manifestation vis-à-vis the local anesthetics in children. The use of midazolam in premedication has also reduced the incidence of the onset of the emergence delirium. These agitations are frequently observed during the use of sevoflurane in anesthesia in the child [18] [19].

Sevoflurane replaced halothane in pediatric anesthesia for safety reasons: a favorable cardiovascular profile, Cardiac index drops significantly with halothane compared to the use of sevoflurane [20]; a large decrease in myocardial contractility of the newborn by a decline speed attachment-detachment from actin-myosin bridges of heart muscle [21]. The Sevoflurane is an alternative in patients at high risk: difficult intubation, asthmatic patients and allergic patients [22].

The oral liquid started early in all our patients [16] [17]. This is an interesting technique for ambulatory surgery.

\section{Conclusion}

This study has shown us that the caudal anesthesia provides comfort and safety for patients. This technique has to be developed more, in an effort to expand its indications in the sub umbilical surgery. Indeed in Côte d'Ivoire peripheral blocks are underdeveloped, difficult to favour for unsufficiency of technical equipment (ultrasound for localization of nerves). 


\section{References}

[1] Aguemon, A.R., Agbonon, H., Atchadé, D., Hounnou, G., Koura, A., Diallo, A.T., et al. (1998) Anesthésie caudale chez l'enfant noir: Faisabilité et tolérance. Cahiers D'Anesthesiologie, 46, 239-243.

[2] Dressen, A.J., Zepka, A.L., Ehounound, M. and N'dri, D. (1991) Anesthésie caudale: Expérience du CHU de Treichville à propos de 50 cas. Publ. Med Afr, 7-10.

[3] Kim, E.M., Lee, J.R., Koo, B.N., Im, Y.J., Oh, H.J. and Lee, J.H. (2014) Analgesic Efficacy of Caudal Dexamethasone Combined with Ropivacaine in Children Undergoing Orchiopexy. British Journal of Anaesthesia, 112, 885-891. https://doi.org/10.1093/bja/aet484

[4] Ivani, G., De Negri, P., Lonnqvist, P.A., Eksborg, S., Mossetti, V., Grossetti, R., Italiano, S., Rosso, F., Tonetti, F. and Codipietro, L. (2003) A Comparison of Three Different Concentrations of Levobupivacaine for Caudal Block in Children. Anesthesia \& Analgesia, 97, 368-371. https://doi.org/10.1213/01.ANE.0000068881.01031.09

[5] Astuto, M., Disma, N. and Arena, C. (2003) Levobupivacaine 0.25\% Compared with Ropivacaine $0.25 \%$ by the Caudal Route in Children. European Journal of Anaesthesiology, 20, 826-830. https://doi.org/10.1097/00003643-200310000-00009

[6] Locatelli, B., Ingelmo, P., Sonzogni, V., Zanella, A., Gatti, V., Spotti, A., Di Marco, S. and Fumagalli, R. (2005) Randomized, Double-Blind, Phase III, Controlled Trial Comparing Levobupivacaine $0.25 \%$, Ropivacaine $0.25 \%$ and Bupivacaine $0.25 \%$ by the Caudal Route in Children. British Journal of Anaesthesia, 94, 366-371. https://doi.org/10.1093/bja/aei059

[7] Cinar, S.O., Isil, C.T., Sahin, S.H. and Paksoy, I. (2015) Caudal Ropivacaine and Bupivacaine for Postoperative Analgesia in Infants Undergoing Lower Abdominal Surgery. Pakistan Journal of Medical Sciences, 31, 903-908.

[8] Giaufre, E. (1990) Anesthésie caudale par injection unique. In: Schult Steinber, O. and Saint Maurice, C., Eds., Anesthésie loco Régionale en Pédiatrie, Arnette, Paris, 81-87.

[9] Giaufre, E., Bruguerolle, B., et al. (1990) The Influence of Midazolam on the Plasma Concentrations of bupivacaine after Caudal Injection of the Mixture of the Local Anesthetics in Children. Acta Anaesthesiologica Scandinavica, 34, 44-46. https://doi.org/10.1111/j.1399-6576.1990.tb03039.x

[10] Meignier, M., Babin, M. and Souron, R. (1982) Anesthésie caudale chez le nourrisson et le petit enfant. Annales Françaises d Anesthésie et de Réanimation, 635-638. https://doi.org/10.1016/S0750-7658(82)80107-X

[11] Ecoffey, C., Lacroix, F., Giaufré, E., Orliaguet, G. and Courrèges, P. (2010) Association des Anesthésistes Réanimateurs Pédiatriques d'Expression Française (ADARPEF) Epidemiology and Morbidity of Regional Anesthesia in Children: A Follow-Up One-Year Prospective Survey of the French-Language Society of Paediatric Anaesthesiologists (ADARPEF). Pediatric Anesthesia, 20, 1061-1069. https://doi.org/10.1111/j.1460-9592.2010.03448.x

[12] Lacroix, F..(2008) Epidemiology and Morbidity of Regional Anaesthesia in Children. Current Opinion in Anesthesiology, 21, 345-349. https://doi.org/10.1097/ACO.0b013e3282ffabc5

[13] Willschke, H., Marhofer, P., Bösenberg, A., Johnston, S., Wanzel, O., Cox, S.G., Sitzwohl, C. and Kapral, S. (2005) Ultrasonography for Ilioinguinal/Iliohypogastric Nerve Blocks in Children. British Journal of Anaesthesia, 95, 226-230.

https://doi.org/10.1093/bja/aei157 
[14] Weintraud, M., Marhofer, P., Bösenberg, A., Kapral, S., Willschke, H., Felfernig, M. and Kettner, S. (2008) Ilioinguinal/Iliohypogastric Blocks in Children: Where Do We Administer the Local Anesthetic without Direct Visualization? Anesthesia \& Analgesia, 106, 89-93. https://doi.org/10.1213/01.ane.0000287679.48530.5f

[15] Constant, I., Gall, O., Gouyet, L., Chauvin, M. and Murat, I. (1998) Addition of Clonidine or Fentanyl to Local Anaesthetics Prolongs the Duration of Surgical Analgesia after Single Shot Caudal Block in Children. British Journal of Anaesthesia, 80, 294-298. https://doi.org/10.1093/bja/80.3.294

[16] Paganelli, M.A. and Popescu, G.K. (2015) Actions of Bupivacaine, a Wideley Used Local Anesthetic, on NMDA Receptor Responses. Journal of Neuroscience, 35, 831-842. https://doi.org/10.1523/JNEUROSCI.3578-14.2015

[17] Moine, P. and Ecoffey, C. (1992) Caudal Block in Children: Analgesia and Respiratory Effect of the Combination Bupivacaine-Fentanyl. Annales Françaises d Anesthésie et de Réanimation, 11, 141-144. https://doi.org/10.1016/S0750-7658(05)80004-8

[18] Ozcan, A., Kaya, A.G., Ozcan, N., Karaaslan, G.M., Er, E., Baltaci, B. and Basar, H. (2014) Effects of Ketamine and Midazolam on Emergence Agitation after Sevoflurane Anaesthesia in Children Receiving Caudal Block: A Randomized Trial. Brazilian Journal of Anesthesiology, 64, 377-381. https://doi.org/10.1016/j.bjan.2014.01.004

[19] Köner, O., Türe, H., Mercan, A., Menda, F. and Sözübir, S. (2011) Effects of Hydroxyzine-Midazolampremedication on Sevoflurane-Induced Paediatric Emergence Agitation: A Prospective Randomised Clinical Trial. European Journal of Anaesthesiology, 28, 640-645. https://doi.org/10.1097/EJA.0b013e328344db1a

[20] Wodey, E., Pladys, P., Copin, C., Lucas, M.M., Chaumont, A., Carre, P., Lelong, B., Azzis, O. and Ecoffey, C. (1997) Comparative Hemodynamic Depression of Sevoflurane versus Halothane in Infants: An Echocardiographic Study. Anesthesiology, 87, 795-800.

[21] Prakash, Y.S., Cody, M.J., Hannon, J.D., Housmans, P.R. and Sieck, G.C. (2000) Comparaison of Volatile Anesthetic Effects on Actin-Myosin Cross-Bridge Cycling in Neonal Versus Adult Cardiac Muscle. Anesthesiology, 92, 1114-1125. https://doi.org/10.1097/00000542-200004000-00030

[22] Bishop, M.J. and Rooke, G.A. (2000) Sevoflurane for Patients with Asthma. Anesthesia \& Analgesia, 91, 245-246.

https://doi.org/10.1213/00000539-200007000-00050 